\title{
O padre, a vila e o galo da torre: padre Marcos de Araújo Costa e a vila de Jaicós (Piauí, 1832-1850)
}

\author{
Marcelo de Sousa Neto ${ }^{1 *}$
}

\section{RESUMO}

O presente estudo discute os primeiros anos de existência da vila de Jaicós, localizada no semiárido piauiense, tomando como fio condutor das análises os espaços de sociabilidades percorridos por padre Marcos de Araújo Costa e que se relacionam com a criaçáo e o cotidiano da vila, entre os anos de 1832 e 1850. Padre Marcos, como ocupante de diversos cargos e funções no quadro administrativo provincial, fez-se atuante no processo de criação e edificação da vila de Jaicós, motivando a escolha metodológica utilizada, que adotou recortes de sua trajetória de vida como ponto de partida da escrita. Entende-se que Padre Marcos percorreu espaços privilegiados para a discussão que se propóe. Para a realização da pesquisa, além da literatura existente sobre o objeto, pôde-se contar com a documentação pertencente ao acervo do Arquivo Público do Estado do Piauí, documentos que possibilitaram novos olhares sobre a constituição e o cotidiano da Vila de Jaicós, bem como reflexôes sobre outras dimensōes do tecido social local no período estudado.

Palavras-chave: história; cidade; biografia; Piauí; século XIX.

\section{The Priest, the Village and the Rooster on the Tower: Father Marcos de Araújo Costa and the Village Jaicós (Piauí, 1832-1850)}

\section{ABSTRACT}

The present study discusses the earliest years of existence of the village of Jaicós, located in the semiarid region of the state of Piauí, through the analysis of the spaces of sociabilities coursed by Father Marcos de Araújo Costa, which are related to the foundation and daily life of the village between the years of 1832 and 1850. Father Marcos, who held several positions within the framework of the provincial administration, became an active player in the

DOI: http://dx.doi.org/10.1590/2237-101X01903810

Artigo recebido em 30 de junho de 2017 e aprovado para a publicação em 11 de dezembro de 2017.

${ }^{1}$ Universidade Estadual do Piauí, Teresina, Piauí, Brasil.

* Professor da Universidade Estadual do Piauí. E-mail: casadapolvora@gmail.com. 
process of foundation and construction of the village of Jaicós. This inspired our choice of methodology, which used parts of his life as the starting point for the writing. It is understood that Father Marcos occupied spaces that are exceptional to the proposed discussion. In order to perform the research, besides the existing literature on the object of the study, we could count on the documentation of the collection of the Public Archive of the State of Piauí, where we found documents that enabled us to develop new views about the constitution and daily life of the village of Jaicós, as well as reflections about other dimensions of the local social fabric during the studied period.

Keywords: history; city; biography; Piauí; $19^{\text {th }}$ Century.

\section{El padre, la villa y el gallo de la torre: Padre Marcos de Araújo Costa y la villa de Jaicós (Piauí, 1832-1850)}

\section{RESUMEN}

El presente estudio discute los primeros ańos de la existencia de la villa de Jaicós, localizada en el semiárido del estado de Piauí, tomando como hilo conductor del análisis los espacios de sociabilidades recorridos por el padre Marcos de Araújo Costa, y que se relacionan con la fundación y cotidiano de la villa entre los años 1832 y 1850. Padre Marcos, como ocupante de diversos cargos y funciones en el cuadro administrativo provincial, se hizo actuante en el proceso de fundación y edificación de la villa de Jaicós, motivando la escogencia metodológica utilizada, que adoptó recortes de su trayectoria de vida como punto de partida para la escritura. Se entiende que Padre Marcos ocupó espacios privilegiados para la discusión que se propone. Para la realización de la investigación, además de la literatura existente sobre el objeto de estudio, se cuenta con la documentación perteneciente al acervo del Archivo Público del Estado de Piauí, documentos que posibilitaron nuevas visiones sobre la constitución del cotidiano de la villa de Jaicós, así como reflexiones sobre otras dimensiones del tejido social local en el periodo estudiado.

Palabras clave: historia; ciudad; biografía; Piauí; siglo XIX. 


\section{Jaicós: de redução indígena a vila}

A origem da vila de Jaicós remonta a uma antiga missão jesuíta, conhecida como aldeia do Cajueiro, que, em 1723, contava com uma capela dedicada à Nossa Senhora das Mercês, construída pelo padre Tomé de Carvalho.

Por suas terras férteis e em razão do potencial ao criatório, em 1787, a aldeia tinha 285 habitantes, entre descendentes indígenas da antiga redução jesuíta e colonos interessados em explorar a região. ${ }^{2}$ Desta forma, logo no princípio do século XIX, seus habitantes obtiveram autorização da coroa portuguesa para a elevação da aldeia à condição de freguesia, sob o nome de Nossa Senhora das Mercês de Jaicós, que, instalada em 1806, ${ }^{3}$ teve como primeiro pároco o padre Antônio Delfino da Cunha. ${ }^{4}$

A nova freguesia, para os indicadores do período, crescia rapidamente em população, ao atrair novos colonizadores interessados no criatório em uma regiāo que oferecia proximidade com as praças consumidoras de Pernambuco e da Bahia e não sofria as constantes ameaças de conflitos com tribos indígenas.

A freguesia, então, continuava o seu crescimento e, em 1831, contava com 5.549 habitantes, número que saltou para 14.695 habitantes em 1856, já então como vila de Jaicós. ${ }^{5}$

Enquanto vila, desmembrada da cidade de Oeiras, Jaicós foi criada pelo Decreto Legislativo de 6 de julho de 1832, que determinava, em seu artigo 5ㅇ․, "Também fica erecta em villa a notável povoação de Jaicoz, que é freguesia há muitos anos, com a denominação de — Villa de Jaicoz — ; sendo o seu termo limitado pela divisão da respectiva freguezia” (sic). ${ }^{6}$

Para sua elevação à condição de vila, Jaicós pôde contar com os esforços e a influência de padre Marcos de Araújo Costa, que, como membro do Conselho de Governo da Província, articulou as diligências necessárias à inclusão da freguesia ao pedido feito à Assembleia Nacional para a criação de novas vilas no Piauí. No entanto, suas ações relacionadas a Jaicós não se resumiram a esse episódio. $\mathrm{O}$ que se pôde observar é que a história de Jaicós, em seus primei-

\footnotetext{
2 BRASIL. BIBLIOTECA NACIONAL. Mapa das cidades, vilas, lugares e freguesias das capitanias do Maranhão e Piaui. 1787. Disponível em: <http://objdigital.bn.br/acervo_digital/div_cartografia/cart543219. jpg >. Acesso em: 11 nov. 2008.

${ }^{3}$ Cf. COSTA, Francisco Augusto Pereira da. Cronologia histórica do estado do Piaui. Rio de Janeiro: Artenova, 1974. p. 381. v. I, a criação Freguesia de Jaicós foi autorizada pela coroa portuguesa em 1801, no entanto, dada a vacância da sede episcopal maranhense, o decreto religioso foi lavrado apenas em 12 de julho de 1805 e sua instalação apenas em 1806. Seu primeiro pároco foi o padre Antônio Delfino da Cunha.

${ }^{4}$ Idem.

${ }^{5}$ BRASIL. BIBLIOTECA NACIONAL. Mapa da divisáo civil e eclesiástica da provincia do Piauí. 1856. Disponível em: <http://objdigital.bn.br/acervo_digital/div_manuscritos/mssII32_22_8.jpg>. Acesso: em 11 nov. 2008.

${ }^{6}$ Pelo mesmo decreto foram ainda criadas as vilas de Poti, São Gonçalo, Príncipe Imperial e Piracuruca. Cf.: BRASIL. RIO DE JANEIRO. Decreto de 6 de julho de 1832. Erige em villas varias povoaçóes da Provincia do Piauhy. In: Colleç̧âo das leis do Império do Brazil: primeira parte. Rio de Janeiro: Typographia Nacional, 1874.
} 
ros anos enquanto vila, tocou, em muitos pontos, a trajetória de vida de Padre Marcos. Dessa condição resultou a decisão de tomar fragmentos da história de vida do padre para recontar um pouco da história de Jaicós.

Torna-se, então, necessário discutir a relação de Padre Marcos com Jaicós e sua importância para a história da vila.

\section{O padre e a vila}

De início, deve ser destacado que, na primeira metade do século XIX, Padre Marcos constitui-se como figura de relevo na conduçáo dos caminhos e na manutenção da ordem imperial na província, ${ }^{7}$ sobretudo como homem de articulação política entre as famílias de elite do centro-sul do Piauí. Suas açóes marcaram boa parte da vida social do período, por meio de sua atuação sacerdotal e educacional, mas também política, ao assumir cargos de destaque na administração piauiense, entre eles, o de presidente da Câmara de Jaicós. ${ }^{8}$

Instalada a vila, em 21 de fevereiro de 1834, Padre Marcos elegeu-se vereador e presidente da Câmara de Jaicós, ${ }^{9}$ cargo que desempenhou até 1848, pouco tempo antes de assumir pela quarta vez a vice-presidência da província, função que desempenhava quando veio a falecer em $1850 .{ }^{10}$ Foi, portanto, do local privilegiado da presidência da Câmara de Jaicós que Padre Marcos acompanhou de muito perto a vida política do Piauí, dispondo de grande influência e prestígio, sobretudo na região centro-sul da Província.

No entanto, a influência de Padre Marcos sobre a região de Jaicós e sobre a administração pública da província data de antes da elevação da vila de Jaicós e torna-se mais visível quando, em 1820, fixou-se em uma fazenda de nome Boa Esperança e transformou sua propriedade, localizada na região do que anos depois viria a integrar a vila de Jaicós, em uma importante rota comercial e de passagem para as províncias ao sul do Piauí.

\footnotetext{
${ }^{7}$ PIAUÍ. APEPI. Resposta ao ofício do Juiz Municipal da Vila de Jaicós, Raimundo José de Carvalho e Sousa, dada pelo Presidente da Provincia, José Antonio Saraiva, sobre o falecimento de Padre Marcos de Araújo Costa. Legislativo Municipal, Jaicós, cx: 92, 16 de dezembro de 1850.

${ }^{8}$ Foi ainda vice-presidente e indicado presidente da província, presidente e vice-presidente do Conselho Geral da Província, vice-presidente do Conselho de Governo da Província, deputado provincial e geral, vereador e presidente da Câmara de Jaicós. Tinha ainda grande prestígio e influência na administração do presidente Manuel de Sousa Martins, seu primo em primeiro grau, que governou o Piauí por cerca de 20 anos, influência que manteve em outras administraçôes.

9 PIAUÍ. APEPI. Ofício encaminhado pela Câmara de Jaicós, ao Presidente da Província, Barão da Parnaíba, dando conta da instalação da Câmara. Legislativo Municipal, Jaicós. cx: 93, 21 de fevereiro de 1834.

${ }^{10}$ Padre Marcos ocupou o cargo de primeiro vice-presidente da província nas administraçóes de Manoel de Sousa Martins, Anselmo Francisco Peretti, Inácio Francisco Silveira da Mota e José Antonio Saraiva.
} 
O local em que funcionou a sede da fazenda deu origem a uma localidade que, após seu falecimento, recebeu o nome de Padre Marcos e que manteve essa denominação quando de sua emancipação, em 1964, ao se desmembrar do município de Jaicós. ${ }^{11}$

A influência política do padre sobre a região pode ser confirmada por meio de algumas das eleiçóes de que participou. Na mais significativa, para o Conselho de Governo da Província, em 1823, saiu-se eleito como conselheiro mais votado - mesmo dividindo votos com seu irmão Inácio Francisco de Araújo Costa, que disputava eleitores na mesma região - assumindo, desse modo, a vice-presidência da província.

Como membro do Conselho de Governo, do Conselho Geral e como deputado provincial, ajudou a deliberar sobre as mais diversas matérias, ${ }^{12}$ no entanto, dentre os cargos que ocupou, sua ligação mais duradoura foi a de vereador e presidente da Câmara de Jaicós, vila que, como dito, ajudou a fundar. ${ }^{13}$

Sobre a Câmara de Jaicós, sua influência foi ainda mais significativa. Eleito vereador na primeira eleiçáo da vila, em 1834, foi ainda o mais votado, assumindo, desse modo, a presidência da casa, em um pleito bastante acirrado, no qual 76 candidatos disputaram 1.057 votos. Desses, Padre Marcos obteve 79 votos contra 62 votos do segundo colocado. Sua preferência entre o eleitorado de Jaicós ainda se manteve em sua última eleição na vila, em 1845, quando obteve 291 votos contra 261 do segundo colocado e, assim, Jaicós constituiu-se como cenário central da atuação de Padre Marcos como político.

No período em estudo, Jaicós constituiu-se em uma importante rota comercial, sobretudo com Pernambuco e Bahia, o que a colocou em uma condiçáo privilegiada em relaçáo a outras vilas da província para o comércio do gado e, especialmente, em relação à circulação de informaçôes. Sua localização beneficiava sobremaneira os negócios do padre como políti-

\footnotetext{
${ }^{11}$ PIAUÍ. Lei Estadual n. 2.566. Cria o município de Padre Marcos. Teresina, 20 jan. 1964.

${ }^{12}$ A título de exemplificação, dentre as matérias tratadas por Padre Marcos como membro do Conselho de Governo, destacam-se as deliberaçôes da sessão de 18 de agosto de 1825, que trataram da impossibilidade de os fazendeiros pagarem os dízimos devidos à província, em razão dos elevados gastos que fizeram colaborando com a manutenção de tropas durante a Guerra da Independência, medida que beneficiava diretamente membros do conselho, inclusive o padre. Pela amplitude de suas decisóes, o Conselho de Governo tinha grande influência no cotidiano da população da província, ocupando-se de matérias muito próximas ao dia a dia desta. Podem ser destacadas entre essas as deliberaçóes do Conselho que determinaram medidas para que fossem vendidos no varejo os gêneros de primeira necessidade, tais como feijão, farinha, milho e arroz, que estavam sofrendo especulação por parte de comerciantes, bem como mandou realizar uma fiscalização sobre os pesos e as medidas dos vendedores (sessão de 25 de agosto de 1825). Determinou, ainda, que fossem expedidas portarias ao juiz de fora da capital e aos comandantes gerais das vilas e ribeiras para que os "ociosos", pessoas sem ocupação certa, fossem obrigados a trabalhar na agricultura em terrenos destinados pelas autoridades para tal fim (sessão de 14 de novembro de 1826). Deliberou tirar de circulação na província moedas de cobre de pequeno valor, denominadas popularmente de "chan", devido à grande quantidade de moedas falsas que apareciam, colocando em dúvida a maior parte de moeda existente em giro (sessão de 13 de maio de 1828). A medida tornou-se impopular, uma vez que gerou dificuldades à populaçáo de menor posse a ter acesso a gêneros de primeira necessidade. Destaca-se ainda a autorização para a construção de uma casa de caridade em Oeiras para atender pobres e enfermos. Padre Marcos foi um dos incentivadores e ajudou em sua execuçáo (seção de 10 de julho de 1829).

${ }^{13}$ BASTOS, Celso de Albuquerque. Dicionário histórico geográfico do estado do Piaui. Teresina: Fundação Cultural Monsenhor Chaves-PMT, 1994.
} 
co e como fazendeiro, uma vez que ele era proprietário de um dos maiores rebanhos de gado do Norte do Brasil, pois em Boa Esperança "pastavam mais de cinco mil cabeças de gado e centenas de carneiros". ${ }^{14}$

À época, o gado representava para Jaicós, como já salientava o próprio padre, “o comércio de maior expressão". ${ }^{15}$ Isso não significa dizer que, como presidente da Câmara, ele não lamentasse a falta de recursos para investimentos e o atraso em que se encontrava seu comércio, trabalhando no sentido de dinamizá-lo, reivindicando, por exemplo, ao presidente da província, José Idelfonso de Sousa Ramos, a criação de uma feira em Jaicós que, como dizia, contribuiria para "promover sua população, o que não pode ter efeito sem os anúncios e determinaçôes superiores". ${ }^{16}$

Nesse documento, Padre Marcos deixa transparecer seu entendimento do poder e da responsabilidade de intervenção do Estado na condução e no planejamento das vilas e cidades e de que a organização destas não poderia ser deixada apenas ao encargo de particulares. No entanto, suas solicitaçôes não obtiveram resposta.

Nesse período, a comunicaçáo e o comércio com a vila eram suficientes, com estradas abertas ligando Jaicós a outras vilas e províncias. $\mathrm{O}$ transporte era realizado nas costas de animais, consistindo no "único meio material de comunicação que mais oportuno se oferece ao local", ${ }^{17}$ dados os inconvenientes do terreno pedregoso para o transporte em carros puxados a animais.

Dessa forma, a vila assumiu uma condição estratégica nos negócios e nos interesses do padre e do grupo familiar do qual fazia parte, o que estimulou, em maior ou menor grau, sua permanência na região. Nesse sentido, se seus vínculos afetivo-familiares concorreram como fatores para a sua permanência em Jaicós, não podem ser esquecidas também as conveniências comerciais e políticas das mais diversas e significativas para o cenário do período.

Traços da personalidade de Padre Marcos e aspectos da vila de Jaicós foram evidenciados, em 1839, por George Gardner, médico e botânico inglês que visitou o clérigo e a vila em 1839, onde dizia ser a casa do padre, na fazenda de Boa Esperança, "o primeiro pouso na estrada para Oeiras, capital provincial". ${ }^{18}$

\footnotetext{
${ }^{14}$ GARDNER, George. Viagem ao interior do Brasil, principalmente nas províncias do Norte e nos distritos do ouro e do diamante nos anos de 1836-1841. Tradução de Milton Amado. Apresentação de Mário Guimarães Ferri. Belo Horizonte: Itatiaia; São Paulo: Edusp, 1975, p. 116. Não foi possível localizar o número preciso de fazendas e propriedades pertencentes a Padre Marcos, no entanto, encontrou-se ainda o registro de duas outras fazendas, Poço da Barra e Povoação, que, juntamente com Boa Esperança e outras grandes fazendas de gado, sofreram derrama, em 1820, como mecanismo encontrado pelo governo da capitania para garantir a oferta de carne verde nos açougues da capital. Cf. SOARES FILHO, Antonio Reinaldo. Oeiras municipal. Teresina: Gráfica Editora Junior, 1992.

${ }^{15}$ PIAUÍ. APEPI. Ofício encaminhado pela Câmara Municipal de Jaicós, ao Presidente da Provincia, Dr. José Idelfonso de Sousa Ramos, informando a comunicação e transportes da Vila. Legislativo Municipal, Jaicós, cx: 93, 14 de abril de 1844.

${ }^{16}$ PIAUÍ. APEPI. Ofício encaminhado à Câmara de Jaicós, pela comissão de fiscalização da construção da prisão municipal, dando conta do andamento das obras. Sala do Poder Executivo, cx: 668-669, 30 de dezembro de 1844. ${ }^{17}$ Idem.

${ }^{18}$ GARDNER, George. Viagem ao interior do Brasil, principalmente nas províncias do Norte e nos distritos do ouro e do diamante nos anos de 1836-1841, op. cit., p. 117.
} 
A narrativa de Gardner oferece uma imagem muito próxima do que representou a casa de Padre Marcos para o Piauí de então: um pouso. Um lugar de passagem e descanso para aqueles que seguiam em direção a Oeiras ou seguiam para as províncias ao sul e em Boa Esperança buscavam refúgio. No entanto, além do lugar físico, Boa Esperança representou também um lugar de pouso simbólico, de maturação de ideias. Lugar em que informaçôes eram produzidas ou chegavam primeiro, ou ainda, último lugar em que as decisóes poderiam ser retratadas.

Muitos políticos, comerciantes, fazendeiros e gente humilde - que por Boa Esperança passaram — receberam atenção e estada. Gardner foi um desses. Demorou-se pouco mais de uma semana, tempo suficiente para ampliar seus conhecimentos e coleçôes botânicas.

Sobre sua estada em Boa Esperança, destacou Gardner:

Durante todo o tempo da nossa permanência fôramos suntuosamente tratados, porque é costume abater o ano todo, diariamente, um boi gordo para uso do proprietário e da gente da fazenda; um ou dois dias antes da nossa partida mataram-se um e secaram-se-lhe a carne para nosso alimento na viagem de modo que, com outros presentes que eu recebera do dono, nossas caixas de provisões se encheram tão bem que pouco mais nos foi necessário até chegarmos a Oeiras. ${ }^{19}$

A abundância retratada por Gardner permite ver um pouco o grau de fartura presente no cotidiano do padre, indicando também sua riqueza e a generosidade com que tratava visitantes da estirpe de Gardner. Talvez com isso pretendendo inclusive melhorar a imagem construída sobre si nas narrativas que dele construísse o pesquisador inglês, como se confirmou com o tempo.

A riqueza e o poder do padre não se limitaram a isso. Ao deixar a fazenda, Gardner seguiu viagem para a sede da vila de Jaicós, trazendo também em sua bagagem cartas de recomendação endereçadas ao presidente da província para que recebesse e providenciasse estada e alimentação ao viajante inglês na capital.

Em Jaicós, Gardner ainda se hospedou, por pouco tempo, em uma grande casa pertencente a Padre Marcos. Seguindo uma tradição herdada de tempos coloniais, era comum que os ricos senhores possuíssem casas nos núcleos urbanos, que funcionavam mais como um símbolo de poder que uma necessidade de fato, preferindo residir no campo onde granjeavam suas posses. ${ }^{20}$

Assim como ocorria em boa parte do Brasil, muitas casas em Jaicós eram destinadas apenas para os dias de festas ou rápidas passagens. Gardner observava que apenas "uns poucos vendedores e comerciantes, como alfaiates, sapateiros etc. residem permanentemente na vila; mas a maioria das casas pertence a fazendeiros vizinhos, que só as ocupam durante o natal e outras festivas". ${ }^{21}$

\footnotetext{
${ }^{19}$ Ibidem, p. 118.

${ }^{20}$ ARAÚJO, Emanuel. O teatro dos vícios: transgressão e transigência na sociedade urbana colonial. Rio de Janeiro: José Olympio, 1993.

${ }^{21}$ GARDNER, George. Viagem ao interior do Brasil, principalmente nas províncias do Norte e nos distritos
} 
De modo geral, os núcleos urbanos no Piauí da primeira metade do século XIX mostravam-se bastante acanhados e com reduzida população. Essa imagem era tâo forte que o próprio presidente da província, o baráo da Parnaíba, deu destaque em documento encaminhado à Assembleia Legislativa Provincial, ressaltando que "as vilas nos dias ordinários ficam desertas de gente, e onde a população está tão espalhada, que o mais vizinho dista do outro quatro ou cinco léguas". 22

\section{A vila, suas construçóes e o galo da torre}

Sobre Jaicós, a influência de Padre Marcos fez-se sentir mesmo em seu traçado urbanístico quando, em seus primeiros anos, Jaicós ficou conhecida na província por seus bons prédios, ${ }^{23}$ sendo que parte destes foi fruto do trabalho de Padre Marcos por meio de construçôes que capitaneou.

Dentre essas construçóes, merecem destaque dois templos católicos. O primeiro deles data de 1820, quando Padre Marcos ergueu em Boa Esperança uma capela dedicada a Santo Antônio, onde celebravam-se missas diariamente e "a comunidade recebia doutrinação e os Sacramentos". ${ }^{24} \mathrm{O}$ segundo, mais tarde, com seus recursos e trabalho, ajudou a erguer a igreja matriz de Jaicós, sob a invocação de Nossa Senhora das Mercês, concluída em 1839. ${ }^{25}$

A capela de Santo Antonio pode ser tomada, no entanto, com outro entendimento. Por todo o Brasil, era comum nas residências a existência de oratórios que consistiam, em geral, em uma mesinha coberta por uma toalha, que abrigavam santos e objetos tidos como sagrados. Nas casas das famílias mais ricas, em alguns casos, era possível encontrar cômodos específicos para oraçôes ou ricos oratórios, nos quais os membros da família dedicavam alguns momentos antes de se recolherem. ${ }^{26}$

No caso do Piauí, a presença de oratórios era escassa, como era pequena a presença de capelas nas fazendas e nos sítios, e poucos habitantes possuíam objetos religiosos. Como observa Brandão, "a expressão concreta do cristianismo reduzia-se à posse de objetos de uso pessoal em ouro e prata como medalhas com imagens de santos e os 'agnus dai'”. ${ }^{27}$

do ouro e do diamante nos anos de 1836-1841, op. cit., p. 118.

${ }^{22}$ PIAUÍ. APEPI. Fala do Barão da Parnaíba [Manoel de Sousa Martins] à Assembleia [Legislativa Provincial], no ato de sua instalação, em 4 de maio de 1835. Registro de Correspondência da Assembleia Legislativa, com o Governo da Província, 1835-1843.

${ }^{23}$ RAFAEL FILHO, José. Sobre a história religiosa de Jaicós. Jaicós, PI: [s.n.], 2008. mimeo.

${ }^{24}$ MELO, Cláudio. Fé e civilização. Teresina: [s.n.], 1991.

${ }^{25}$ Cf.: CARVALHO JÚNIOR, Dagoberto Ferreira de. A talha de retábulos no Piauí. Recife: Comitê Norte Nordeste de História da Arte, 1990; CASTELO BRANCO, Miguel de Sousa Borges Leal. Apontamentos biográficos de alguns piauienses e outras pessoas notáveis que ocuparam cargos de importância. Teresina: Tipografia da Imprensa, 1879; COSTA, Francisco Augusto Pereira da. Cronologia histórica do estado do Piauí, op. cit., v. I. ${ }^{26}$ SODRÉ, Nelson Wernek. Panorama do segundo império. 2. ed. Rio de Janeiro: Graphia, 1998.

${ }^{27}$ BRANDÁO, Tanya Maria Pires. Matrimônio: legalidade e sagração da família no Piauí colonial. In: 
Em meio a uma sociedade em que a religiosidade se forjou pela vivência prática e com símbolos escassos, Padre Marcos levou à frente a construção de uma capela que, grosso modo, não deixou de ser o oratório de sua casa, símbolo de sua riqueza e de sua autoridade religiosa. A referida capela não mais existe, substituída hoje pela Matriz de Santo Antonio, no município de Padre Marcos (PI), impossibilitando o estudo dos traços arquitetônicos da construção original.

Entretanto, a maior contribuição de Padre Marcos como construtor foi, todavia, a construção da igreja matriz de Jaicós, em substituição à antiga capela edificada pelos jesuítas em 1723.

Por todo o Brasil, sobretudo nos centros urbanos, as construçôes religiosas destacavam-se por sua importância, imponência e solidez se comparadas com as demais construçôes e residências dos centros, marcadas por sua simplicidade e funcionalidade. Durante o ciclo do ouro, essas construçóes ganharam ainda mais rebuscamento e luxo, enriquecidas com ouro e pedras preciosas, sobretudo em Minas Gerais e na Bahia.

A beleza e a força que as igrejas demonstravam ter eram motivo de orgulho das populaçóes, que se sentiam lisonjeadas com a grandiosidade e a riqueza das construçóes por devoçáo e por terem a sensação de compartilhar dessa riqueza como também sendo sua. ${ }^{28}$

No Piauí, as construçôes religiosas, sobretudo as igrejas matrizes, foram marcadas pela importância e pela beleza das construçôes, como é o caso, no século XIX, da Igreja de Nossa Senhora das Mercês, em Jaicós.

As construçôes realizadas por Padre Marcos funcionaram como "táticas de fazer crer", usando expressão cara a Michael de Certeau, ${ }^{29}$ materializando em gestos e obras, com o intuito de serem vistas, provando à população suas convicções e suas posições religiosas e políticas, revertendo-se em vantagens pessoais, capitalizadas no prestígio social que desfrutava mediante tais realizaçóes.

Mesmo sendo equivocada a informação de que teria arcado sozinho com os custos dessa construção, uma vez que o governo da província e muitos paroquianos também auxiliaram com recursos para construção da matriz de Jaicós, é certo que Padre Marcos participou com uma grande quantidade de recursos e esforços. Castelo Branco ${ }^{30}$ e Costa $^{31}$ estimam que concorreu com quantia superior a 10:000\$000 réis (dez contos de réis), além de outros serviços que prestou para auxiliar a conclusão. Por outro lado, acredita-se que o apoio recebido da população de Jaicós e do governo da província na construção da matriz em muito se deve a cobranças,

SILVA, Maria Beatriz Nizza. Sexualidade, família e religião na colonização do Brasil. Lisboa: Livros Horizonte, 2001, p. 180.

${ }^{28}$ HAUCK, João Fagundes et. al. História da Igreja no Brasil: ensaio de interpretação a partir do povo: segunda época: século XIX. 4. ed. Petrópolis, RJ: Vozes, 2008.

${ }^{29}$ CERTEAU, Michel de. A invenção do cotidiano: artes de fazer. Tradução de Ephrain F. Alves. Petrópolis, RJ: Vozes, 1994.

${ }^{30}$ CASTELO BRANCO, Miguel de Sousa Borges Leal. Apontamentos biográficos de alguns piauienses e outras pessoas notáveis que ocuparam cargos de importância, op. cit., 1879.

${ }^{31}$ COSTA, Francisco Augusto Pereira da. Cronologia histórica do estado do Piauí, op. cit., 1974. 
incentivos e, principalmente, à credibilidade de Padre Marcos, que, à frente dessa empreitada, conseguiu atrair esses recursos.

Construída em estilo rococó com uma torre, ${ }^{32}$ a matriz de Jaicós foi concluída em 1839 , construção somente possível graças "ao trabalho de benemerência do Padre Marcos de Araújo Costa", ${ }^{33}$ que teve o cuidado, inclusive, de mandar colocar um galo de bronze na torre da igreja, costume europeu que também podia ser visto em muitas igrejas brasileiras, tradição que, conforme Rafael Filho, ${ }^{34}$ o padre trouxe de Portugal, acrescentando esse serviço à sua obra missionária e educacional, traduzido pelo belo e importante templo construído.

É curioso lembrar que, em 1947, o galo de bronze da torre central da Matriz de Nossa Senhora das Mercês veio ao chão após ter sido atingido por um raio, mas foi logo recolocado por ordem do vigário da paróquia à época, padre José Inácio Madeira. ${ }^{35} \mathrm{O}$ galo da torre ainda inspirou outros símbolos importantes de Jaicós, podendo sua representação ser encontrada na bandeira e no hino da cidade.

Não se pode ignorar, no entanto, que o governo da província também colaborou com importante soma de recursos para a construção da igreja matriz. Em 1833, considerando um período em que quase todas as matrizes estavam em péssimo estado, ${ }^{36} \mathrm{a}$ administração provincial destinou 8:000\$000 (oito contos de réis) para as obras públicas e reformas das igrejas matrizes. Desse total, a matriz de Jaicós recebeu 2:000\$000 (dois contos de réis), indicando uma forte preocupação com um espaço que era símbolo material e imaterial da sociedade da época e também era o espaço de atuação de Padre Marcos. Esse é outro exemplo que ilustra o poder e a influência de Padre Marcos junto ao governo provincial, já que um quarto dos gastos do governo com obras públicas para aquele ano foram destinados para a matriz de Jaicós, tendo essa construção sido tratada como prioridade entre as obras do governo.

\footnotetext{
${ }^{32}$ Cf. RAFAEL FILHO, José. Sobre a história religiosa de Jaicós, op. cit., a segunda torre com o relógio e o corredor lateral direito da igreja foram construídos em comemoração ao centenário da igreja, obras iniciadas pelo padre Miguel dos Reis Melo e inauguradas pelo padre José Zimmerman em 1937.

${ }^{33}$ CARVALHO JÚNIOR, Dagoberto Ferreira de. A talha de retábulos no Piauí, op. cit.

${ }^{34}$ Cf. RAFAEL FILHO, José. O galo na torre. Disponível em: <http://www.jaicos.com/paroquia200.html>. Acesso em: 26 fev. 2007, "o galo é tido pelos poetas e trovadores como símbolo do Alvorecer, do amanhecer de um novo dia, novo tempo de recomeçar. Simboliza também o vigilante que espera pela Aurora. Pela tradição, é visto na representaçáo da gruta de Belém nos diversos presépios que são produzidos em honra do nascimento de Jesus, porque teria sido um dos animais presentes na manjedoura em que a Mãe de Deus colocara o Deus-Menino, porque não encontraram lugar para Ele na cidade dos homens”. Mas o galo tinha também uma finalidade social e meteorológica, pois, "colocado no centro de uma base de ferro que lhe permite girar 360 graus, sobre si mesmo e por seu desenho aerodinâmico, tem o bico sempre voltado para o lado de onde vem o vento; e a base tem quatro hastes também de ferro, em forma de raios, cada uma com cerca de sessenta centímetros de comprimento: uma apontada para o Norte, com a letra N; uma para o Sul, com a letra S; uma para o Leste com a letra L ou E, e por último a que aponta para Oeste, com a letra $\mathrm{O}$ ou W, expondo, permanentemente, as pontas cardeais".

${ }^{35}$ RAFAEL FILHO, José. O galo na torre, op. cit.

${ }^{36}$ PIAUÍ. APEPI. Fala do Barão da Parnaíba [Manoel de Sousa Martins] à Assembleia [Legislativa Provincial], no ato de sua instalação, em 4 de maio de 1835. Registro de Correspondência da Assembleia Legislativa com o Governo da Província, 1835-1843.
} 
É importante notar ainda que, no período, a maior parte das obras da província estava paralisada pela falta tanto de recursos financeiros quanto de materiais e de pessoal qualificado. ${ }^{37}$ Assim, sem a influência e o auxílio financeiro de Padre Marcos, a matriz de Jaicós seria apenas mais um dos "templos em ruínas, paróquias destituídas de pastores", ${ }^{38}$ "como se acha[vam] quase todas as Matrizes da Província". ${ }^{39} \mathrm{O}$ prestígio gozado pelo clérigo, capaz de interferir nas prioridades e nas decisóes da administraçáo provincial, bem como seu poder econômico ficam notórios nesse exemplo da construção da matriz de Jaicós.

Esse episódio remete ainda à conquista de autoridade discutida por Certeau, ao tratar dos espaços de poder ocupados por membros da Igreja, que muitas vezes suprimiam a insuficiência de aparato técnico-administrativo pelos "sistemas de clientela, de cooptaçôes, de "legitimidades". .0 $^{0}$

Ainda a respeito da construção da matriz, o presidente da província, em prestaçáo de contas de 1838, informava que:

A matriz de Jaicós está a concluir-se, sendo esta obra a de menos dispêndio para a província, por haverem a ela concorrido muitos de seus paroquianos, sendo entre eles o reverendo Marcos de Araújo Costa, que a tem coadjudado, contribuído com seus dinheiros, incomparável zelo, e influência. ${ }^{41}$

Ao esclarecer sobre os recursos que contribuíram para a construção da matriz de Jaicós, o presidente da província, Manoel de Sousa Martins, revela o poder econômico e o prestígio de Padre Marcos junto a seus paroquianos, mas também tenta eximir seu governo de acusaçôes em relação ao envio de recursos para favorecer uma obra executada por seu primo.

A respeito do período em que esteve à frente da matriz de Jaicós como pároco, por meio da documentação consultada nesta pesquisa, foi encontrado registro de 1834, no qual o padre assina como vigário em Jaicós. Trata-se de ofício da Câmara de Jaicós ao presidente da província, de 17 de junho de 1834, contendo a lista dos jurados a servirem na vila. No termo de apuração

${ }^{37}$ PIAUÍ. APEPI. Fala que recitou o Exmº Sr. Barão da Parnaíba [Manoel de Sousa Martins] Presidente desta Província do Piauí na ocasião da abertura da Assembleia Legislativa Provincial, no 9o de julho do ano de 1838. Sala do Poder Legislativo. Registro de Correspondência da Assembleia Legislativa com o Governo da Província, 1835-1843.

${ }^{38}$ Cf. Resposta da Assembleia Legislativa Provincial à fala do Presidente da Província, de 1838. In: PIAUÍ. APEPI. Sala do Poder Legislativo. Registro de Correspondência da Assembleia Legislativa com o Governo da Província, 1835-1843.

${ }^{39}$ PIAUÍ. APEPI. Fala que recitou o Exmº Sr. Visconde da Parnaiba [Manoel de Sousa Martins] Presidente desta Provincia do Piaui na ocasião da abertura da Assembleia Legislativa Provincial, em 7 de julho de 1843. Sala do Poder Legislativo. Registro de Correspondência da Assembleia Legislativa com o Governo da Província, 1835-1843.

${ }^{40}$ CERTEAU, Michel de. A invençâo do cotidiano: artes de fazer, op. cit., p. 180.

${ }^{41}$ PIAUÍ. APEPI. Fala que recitou o Exmo Sr. Barão da Parnaíba [Manoel de Sousa Martins] Presidente desta Província do Piauí na ocasião da abertura da Assembleia Legislativa Provincial, no 9o de julho do ano de 1838a. Sala do Poder Legislativo. Registro de Correspondência da Assembleia Legislativa com o Governo da Província, 1835-1843. 
anexado ao documento, o secretário da Câmara, Antonio Barbosa de Lucena, frisa ser Padre Marcos vigário da vila, tendo assumido no impedimento do antecessor. ${ }^{42}$ Não foi possível, por outro lado, precisar se Padre Marcos assumiu de forma definitiva a paróquia da vila ou apenas de maneira provisória. Bastos ${ }^{43}$ no entanto, informa ser Padre Marcos vigário em Jaicós, em 1837, provavelmente ainda respondendo pelo cargo assumido desde 1834. O Livro de Tombo da paróquia, referente ao período em estudo, poderia apontar a direçáo de alguma resposta, e mesmo responder se Padre Marcos foi sacerdote colado ou encomendado, entretanto, o livro não foi encontrado na paróquia. Sobre o paradeiro desse livro, só é possível traçar suposições: talvez devorado pelas tiranias do tempo e o descaso dos homens, talvez queimado entre os livros de registros de batismo atacados por cupins de que falava o padre José Zimmermann, pároco em Jaicós entre 1933 e $1939 .{ }^{44}$ Contudo, é certo que Padre Marcos atuou ativamente na vida religiosa da vila e, mesmo que por curtos intervalos, respondeu como vigário de Jaicós.

\section{O padre e o cotidiano da vila}

O interesse de Padre Marcos foi além da construção de igrejas. Sua preocupação com a infraestrutura e com o desenvolvimento socioeconômico da vila de Jaicós, e inclusive do restante da província, ficou marcada em outras iniciativas.

As dificuldades de receitas representavam uma constante na vida das vilas piauienses em toda a primeira metade do século XIX, o que trazia sérios embaraços à administração pública. ${ }^{45}$ Isso também se aplicava a Jaicós, que, embora não tivesse problemas com suas prestaçóes de contas, apresentava recursos financeiros muito limitados. ${ }^{46}$

Durante a primeira metade do século XIX, era considerado comum o fato de as prestaçôes de contas encaminhadas pelas Câmaras de diversas vilas à Assembleia Provincial apresentarem problemas e serem rejeitadas. No entanto, nas prestações de contas encaminhadas pela vila de Jaicós à Assembleia Provincial, sob a gestão de Padre Marcos, não se observou esse tipo de problema. Pode-se atribuir isso tanto ao fato de o padre ser um bom adminis-

\footnotetext{
${ }^{42}$ PIAUÍ. APEPI. Ofício encaminhado pela Câmara de Jaicós, ao Presidente da Província, Barão da Parnaíba, dando conta da instalação da Câmara. Legislativo Municipal, Jaicós. cx: 93, 21 de fevereiro de 1834a.

${ }^{43}$ BASTOS, Celso de Albuquerque. Dicionário histórico geográfico do estado do Piauí, op. cit., 1994.

${ }^{44}$ OLIVEIRA, José do Carmo. O bicentenário da paróquia de Nossa Senhora das Mercês de Jaicós — Piauí (1805-2005). Disponível em: <http://www.jaicos.com.paroquia200.htm>. Acesso em: 17 maio 2006.

${ }^{45}$ PIAUÍ. APEPI. Fala do Barão da Parnaíba [Manoel de Sousa Martins] à Assembleia [Legislativa Provincial], no ato de sua instalação, em 4 de maio de 1835. Registro de Correspondência da Assembleia Legislativa, com o Governo da Província, 1835-1843.

${ }^{46}$ PIAUÍ. APEPI. Fala que recitou o Exmº Sr. Barão da Parnaíba [Manoel de Sousa Martins] Presidente desta Provincia do Piaui na ocasião da abertura da Assembleia Legislativa Provincial, no 9o de julho do ano de 1838. Sala do Poder Legislativo. Registro de Correspondência da Assembleia Legislativa, com o Governo da Província, 1835-1843.
} 
trador público quanto também ao bom relacionamento mantido pelo sacerdote com aquela casa legislativa.

No ano financeiro de 1841/1842, por exemplo, as vilas de São Gonçalo, Campo Maior, Parnaguá, Príncipe Imperial e Marvão tiveram suas contas reprovadas pela Assembleia. A principal alegação dos deputados foi falta de fundamento legal nos gastos realizados. ${ }^{47}$

Sobre os recursos financeiros da vila de Jaicós, no entanto, as limitaçóes eram as mais diversas. Tomando por base o ano financeiro de 1838/1839, a Câmara da Vila tinha como previsão de receitas provinciais para o período apenas $169 \$ 640$ réis, a serem empregados com as gratificaçóes do Secretário e o Porteiro da Câmara (art. 1º), com o expediente da Câmara (art. 2을 e com a compra de alguns utensílios para a vila, especificados como "balanças, pesos e medidas para padróes" (art. 3ํ)..$^{48}$

A carência de recursos financeiros agravou-se nos anos que se seguiram, o que pode ser ilustrado com a resposta à solicitação feita pelo presidente da província, José Idelfonso de Sousa Ramos, sobre o andamento das obras públicas em Jaicós, em 1844. Padre Marcos informou que tinha "o dissabor de informar a V. Ex ${ }^{a}$ que nenhuma se pôs em prática por lhe faltarem meios, a vista da tenuidade de sua receita que apenas chega para as despesas indispensáveis". ${ }^{49}$

Diante das dificuldades de recursos financeiros da vila, Padre Marcos não se furtou de solicitar ao governo da província recursos e obras para Jaicós. Dentre essas, em 1834, consta o pedido de construção de uma prisão, onde deveria funcionar também a Câmara Municipal, em razão da recente criação da vila..$^{50}$

O mesmo pedido foi renovado em 1836, usando como argumento questóes de ordens morais. Segundo correspondência enviada ao presidente da província, solicitando a construção da prisão, Padre Marcos entendia que esta construção se fazia urgente em virtude do "infeliz progresso que vai tendo a imoralidade pela falta de polícia em consequência de não haver nesta vila um edifício que lhe sirva de prisão". ${ }^{51}$

A falta de prisões também era um problema comum a outras vilas, ${ }^{52}$ problema que se arrastou em Jaicós até 1844, quando, não vendo atendidas suas solicitaçóes de construção do

\footnotetext{
${ }^{47}$ PIAUÍ. APEPI. Ofício da Assembleia Provincial ao Presidente, que dá conta das Receitas e Despesas das Câmaras Municipais no ano financeiro de $1^{\circ}$ de outubro de 1841 a 30 de setembro de 1842. Registro de Correspondência da Assembleia Legislativa com o Governo da Província, 1835-1843.

${ }^{48}$ PIAUÍ. APEPI. Lei Provincial de 4 de outubro de 1838. Oeiras: Tipografia Oficial, 1838.

${ }^{49}$ PIAUÍ. APEPI. Ofício da Câmara Municipal da Vila de Jaicós, ao Presidente da Província, Dr. José Idelfonso de Sousa Ramos. Legislativo Municipal, Jaicós, cx: 93, 12 de abril de 1844.

${ }^{50}$ PIAUÍ. APEPI. Ofício encaminhado pela Câmara Municipal de Jaicós ao Presidente da Província, Barão da Parnaíba, solicitando a construção de uma prisão na Vila. Legislativo Municipal, Jaicós, cx: 93, 3 de novembro de 1834.

${ }^{51}$ PIAUÍ. APEPI. Ofício encaminhado pela Câmara Municipal de Jaicós ao Presidente da Província, Barão da Parnaíba, solicitando a construção de uma prisão na Vila. Legislativo Municipal, Jaicós, cx: 93, 4 de julho novembro de 1836.

52 PIAUÍ. APEPI. Fala com que o Exmº Sr. Barão da Parnaíba [Manoel de Sousa Martins] abriu a sessão ordinária da Assembleia [Legislativa] Provincial, em 13 de julho de 1837a. Registro de Correspondência da Assembleia Legislativa com o Governo da Província, 1835-1843.
} 
prédio, Padre Marcos colocou-se, às suas custas, a adaptar um grande prédio que construiu na sede da vila para que servisse de prisáo.

Essa intervenção, seja como proposição, seja com o financiamento da construção, revela uma atuação que ultrapassa a missão do clérigo. Com isso, assinala-se mais uma significativa participação no cenário da época, intervindo não apenas nos interditos morais e ideológicos, como também contribuindo para a construçáo do mais forte símbolo de interditos materiais: a prisão.

Para acompanhar o andamento das obras, nomeou-se, então, uma comissão de vereadores $^{53}$ da vila que considerou os requisitos exigidos "plenamente preenchidos e até mesmo excedidos". ${ }^{54}$ A construção edificada por Padre Marcos foi cedida para o governo para que servisse de casa para a Câmara, ao mesmo tempo também funcionava como fórum, cadeia e quartel do destacamento policial. Tal espaço físico tornou-se mais uma relevante contribuição de Padre Marcos na cartografia física e sociopolítica da cidade de Jaicós e da província.

Posteriormente, Padre Marcos recebeu uma indenização em relação aos seus gastos com a construção, na quantia de 4:000\$000 (quatro contos de réis). No entanto, segundo Castelo Branco, os recursos aplicados pelo Padre com a obra da Câmara de Jaicós custaram "para mais de 6:000\$000 (seis contos de réis)", 55 valor bem acima do que recebera do poder público. $\mathrm{O}$ ajuste dessas contas somente veio mais tarde, após sua morte.

Entretanto, o padre soube capitalizar outros dividendos com a construção no que concerne à sua dimensão simbólica, sobretudo porque, nesse caso, a construção arquitetônica era a materialização de um poder considerado exclusivo do Estado: a força. Expressado pelos seus símbolos máximos; cadeia, quartel, destacamento policial e fórum, além do centro de poder político da vila, a Câmara Municipal, Padre Marcos agrega, assim, sua imagem em Jaicós como representativa do próprio Estado.

A marca de seu trabalho também se fez sentir na capital da Província, onde foi um dos incentivadores da construção de uma instituição de caridade para abrigar pobres e enfermos. ${ }^{56}$ Para a construçáo dessa casa de caridade, Padre Marcos também contribuiu com recursos e, segundo documento da época, ele

(...) se ofereceu voluntariamente para pedir esmolas na freguesia de Jaicós, aonde mora, a fim de aumentar-se o fundo determinado para sobredito estabelecimento de caridade; e sendo ouvido com especial agrado o seu oferecimento; resolveu-se mais que o senhor presidente lhe faça expedir o competente título autorizando-o para isso. ${ }^{57}$

\footnotetext{
${ }^{53}$ Formaram a comissão: José Rodrigues Coelho, Manoel Francisco Ramos, Miguel da Costa Veloso e Manoel Joaquim dos Santos.

${ }^{54}$ PIAUÍ. APEPI. Ofício encaminhado à Câmara de Jaicós, pela comissão de fiscalização da construção da prisão municipal, dando conta do andamento das obras. Sala do Poder Executivo, cx: 668-669, 30 de dezembro de 1844. ${ }^{55}$ CASTELO BRANCO, Miguel de Sousa Borges Leal. Apontamentos biográficos de alguns pianienses e outras pessoas notáveis que ocuparam cargos de importância, op. cit., p. 137; COSTA, Francisco Augusto Pereira da. Cronologia histórica do estado do Piaui, op. cit., p. 252.

${ }^{56}$ PIAUÍ. APEPI. Atas do Conselho Geral da Provincia (1825-1829). 3ª seção de 10 de julho de 1829.

${ }^{57}$ Idem.
} 
Mas as obras do hospital de caridade, cuja construção foi autorizada pela Lei Provincial $\mathrm{n}^{\circ}$ 9, de 4 de julho de 1835, avançavam a passos muito lentos, em razão da dificuldade de liberação de recursos da província. Sua construção somente foi concluída, em 1849, sob administração do presidente Anselmo Francisco Peretti.

O conhecimento e a intimidade de Padre Marcos sobre o cotidiano socioeconômico de Jaicós podem ainda ser verificados, por exemplo, quando ao ser questionado, em 1844, pelo presidente da província, José Idelfonso de Sousa Ramos, sobre a viabilidade do plantio de chá na região, o clérigo responde que não se tem realizado experiências com o plantio do chá em razáo de "seu meio seco", ${ }^{58} \mathrm{sem}$, no entanto, demonstrar nenhuma censura, tristeza ou a tentativa de oferecer alternativas à condição em que estava a agricultura no Piauí, o que se poderia esperar de um estudioso das plantas, como era reconhecido. Antes disso, demonstra o reconhecimento de outra vocação da regiáo, a pecuária, que dizia ser a principal riqueza de seu município. $\mathrm{O}$ amor à botânica parece ter sido mitigado perante as circunstâncias geográficas, econômicas e sociais nas quais estava inserido, reconhecendo outras potencialidades econômicas e sociais, que orbitavam em torno das fazendas de gado. Estas, por sua vez, constituíram-se núcleos efetivos de povoamento, produzindo e consumindo bens e produtos, bem como socializando novos membros em seus valores e normas sociais.

Padre Marcos foi herdeiro de uma elite local de fazendeiros que herdou bens materiais, prestígio social e poder político, e que aprendeu a multiplicá-los, valendo-se da condição de "homem de ideias" e "homem do sagrado" e que encontrou em Jaicós os espaços necessários para a consolidação e a ampliação do patrimônio político, econômico e social de seu grupo familiar.

Filho de Marcos Francisco de Araújo Costa, juiz ordinário e de órfăos de Jerumenha e juiz ordinário em Oeiras, sargento-mor e ouvidor geral em Oeiras e membro da Junta Governativa da Capitania (1784/1786), Padre Marcos recebeu a influência do pai em assuntos jurídicos, experiências que trouxe para sua vida política e que se refletiam nos documentos produzidos por ele, na condição de presidente da Câmara de Jaicós, ao observar-se um forte apego à legislação, à doutrina e à jurisprudência imperial como fundamentos de seus pedidos e de suas providências.

Seu conhecimento jurídico e sua força política podem ser ainda exemplificados em temas relativos ao cotidiano da população de Jaicós. Em representação feita à Assembleia Provincial, em 1837, Luiz Xavier de Araújo, procurador dos habitantes da vila de Jaicós, solicitou que fosse suspenso o artigo 36 do Código de Postura ou Código Policial da Vila, cuja elaboração contou com a ajuda de Padre Marcos, e que em seu artigo 36 obrigava os agricultores a abaterem pássaros danosos à lavoura. ${ }^{59}$

\footnotetext{
${ }^{58}$ PIAUÍ. APEPI. Ofício da Câmara Municipal da Vila de Jaicós ao Presidente da Provincia, Dr. José Idelfonso de Sousa Ramos. Legislativo Municipal, Jaicós, cx: 93, 12 de abril de 1844.

59 PIAUÍ. APEPI. Ofício e Relatório encaminhado pela Câmara da Vila de Jaicós à Assembleia Provincial, prestando informaçóes sobre a representação impetrada por Luis Xavier de Araújo. Sala do Poder Legislativo. Legislativo, cx: 122, 1르 legislatura, de 4 de julho de 1837.
} 


\section{$\mathrm{O}$ artigo trazia o seguinte texto:}

Todos os habitantes deste município são obrigados a apresentar anualmente no mês de julho ao fiscal do respectivo distrito tantas cabeças, sejam de periquitos, passarinhos casacas ou cabeças vermelhas, quanto correspondam em número de vinte a cada pessoa do sexo masculino de quinze anos acima que serve em cada fogo, ou família. Pena de pagar seis mil reis para as obras do Conselho aquele que náo apresentar o número completo respectivamente ao número de pessoas que tiver em sua companhia. ${ }^{60}$

Luiz Xavier balizou seus argumentos no despropósito do artigo do Código de Postura, considerando não ser elevado o número de tais pássaros na vila, assim como o excesso da intervenção do poder público nesse campo.

Todavia, a presença de pássaros danosos à lavoura, sobretudo periquitos e papagaios, representou por muito tempo um problema enfrentado pelos agricultores piauienses, que tinham ainda dificuldades maiores a enfrentar com a inconstância das chuvas. Se pragas agrícolas surgidas posteriormente ou presentes em pequena escala, como insetos e doenças agrícolas, não assustavam o homem do campo àquele instante, muitos pássaros atacavam plantações comendo frutos, plantas e mesmo sementes, trazendo prejuízos à produção.

Como presidente da Câmara, Padre Marcos encaminhou uma longa e circunstanciada explicação sobre a validade e a necessidade de tal medida que, segundo ele, já apresentava bons efeitos com a melhora dos resultados alcançados pela agricultura na vila, deixando transparecer seu profundo conhecimento do direito, da botânica e da regiáo em questáo.

Entre seus argumentos, destacou que o crescimento exponencial das aves traria dentro de pouco tempo embaraços os mais sérios à já tão frágil agricultura da vila e questionava ainda a competência da Assembleia Provincial em julgar o caso, uma vez que esta não seria instância própria para discutir as necessidades e especificidades da regiáo, cabendo à Câmara da Vila proceder tais encaminhamentos. ${ }^{61}$ A representação encaminhada por Luiz Xavier, a quem Padre Marcos considerava ser "desconhecido neste município", ${ }^{62}$ não obteve êxito.

No ano seguinte a Assembleia Provincial aprovou resolução, de número 96, de 4 de outubro de 1838, obrigando a todos os possuidores de roças no distrito do município de Amarante a "apresentarem anualmente vinte cabeças de periquitos ou de outro animal daninho" às autoridades competentes, sob pena de multa. ${ }^{63}$ Certamente, os argumentos utilizados por

\footnotetext{
${ }^{60}$ PIAUÍ. APEPI. Posturas policiais do município da vila de Jaicós, Art. 36. Sala do Poder Legislativo. Legislativo Municipal de Jaicós, cx: 92, de 4 de outubro de 1834.

${ }^{61}$ PIAUÍ. APEPI. Ofício e Relatório encaminhado pela Câmara da Vila de Jaicós à Assembleia Provincial, prestando informaçóes sobre a representação impetrada por Luis Xavier de Araújo. Sala do Poder Legislativo. Legislativo, cx: 122, 1로 legislatura, de 4 de julho de 1837.

${ }^{62}$ Idem.

${ }^{63}$ PIAUÍ. APEPI. Resolução no 96, de 4 de outubro de 1838. Obriga aos possuidores de roças no distrito do municipio de Amarante a apresentarem anualmente vinte cabeças de periquitos ou outro animal danoso à agricultura. Sala do Poder Legislativo/02, Documentos Avulsos/02, 1838.
} 
Padre Marcos contra a representação de Luiz Xavier influenciaram a decisão dos deputados para aprovação da resolução, metade deles ex-colegas de assembleia do padre.

O episódio da representação encaminhada por Luiz Xavier traz à discussão importantes pontos sobre a atuação política de Padre Marcos, inclusive referente a dimensóes cotidianas da vida social de Jaicós no período. Entre esses pontos, destaca-se a atuaçáo do intelectual militante que, como especialista em plantas e conhecedor dos ciclos agrícolas, entendia que, naquele momento, os pássaros, em meio à abundância de alimentos e sem predadores naturais, representavam uma ameaça à agricultura da vila.

Àquele instante, os agricultores da vila não percebiam ou não se comprometiam com o controle da populaçáo de pássaros danosos à agricultura, pois, para eles, esse controle representava mais uma obrigação do que uma necessidade de resultados práticos.

Nesse ponto surge o político que trouxe para o ordenamento jurídico o entendimento do especialista, no caso em análise, o discurso autorizado do especialista em plantas. Mas a passagem do entendimento do especialista para a legislação não ocorria sem resistências, já que ela foi elaborada à revelia da populaçáo ou pelo menos de parcela da população, representada por Luiz Xavier.

O episódio ilustra também a atuaçáo dos opositores ao padre, bem como o modo como ele conseguia fazer frente a essas reaçôes e a maneira como impunha seu desejo e do grupo que representava. Mais que isso, demonstra seu empenho na defesa de seus interesses. No caso em questão, conseguiu despertar atençáo para o tema e influenciar decisões em outros espaços e instâncias, uma vez que tinha a fala do autorizado por sua rede social. Era a fala do especialista, do parente, do proprietário, do político e, se não bastasse, do representante de Deus. $\mathrm{Na}$ criação de seus lugares de fala, Padre Marcos foi capaz de operar no sentido de criar estratégias capazes de "produzir, mapear e impor" ${ }^{64}$ seus interesses à rede social a qual fazia parte.

Esse evento também demonstra a capacidade de articulação e de força que Padre Marcos tinha de se impor em meio às adversidades. Seus gestos representavam estratégias e sua capacidade de manipulação das relações de força e de oposição às táticas do fraco, que lhe permitiam adequar-se ao que Michael de Certeau definiu como "capitalizar vantagens conquistadas, preparar expansóes futuras e obter assim para si uma independência em relação à variabilidade das circunstâncias". ${ }^{65}$

Essa capacidade de capitalizar vantagens e de adaptar-se às circunstâncias fez com que Padre Marcos permanecesse no centro de decisōes do aparelho de Estado mesmo após o afastamento de Sousa Martins, o que evidencia que sua força política ia além das alianças estabelecidas com o visconde da Parnaíba. Até mesmo porque o longo governo do visconde é atribuído, em boa medida, à influência do padre, tendo ele sido figura de destaque incontestável nessa administração.

\footnotetext{
${ }^{64}$ CERTEAU, Michel de. A invenção do cotidiano: artes de fazer, op. cit., p. 92.

${ }^{65}$ Ibidem, p. 99.
} 


\section{Consideraçóes finais: marcas que desafiam o tempo}

Como foi possível observar, as marcas deixadas por Padre Marcos fizeram-se sentir nos mais diversos espaços e segmentos sociais da vida piauiense e, de forma especial, jaicoense, por meio de seu trabalho como religioso, fazendeiro, político e educador.

A respeito de seu trabalho, por exemplo, como educador, o presidente Zacarias de Góis e Vasconcelos deixou um importante testemunho. Dizia ele:

O ensino particular pode dizer-se que é nenhum, pois de primeiras letras há algumas escolas a cargo de particulares, com pequeno número de alunos. Aparece, todavia, como notável exceção desta regra o ensino do Rev. Padre Marcos de Araújo Costa em sua fazenda Boa Esperança. Vós sabeis senhores, que de longo tempo tem esse ancião respeitável formado número de moços não só primeiras letras, senão latim, francês, retórica, filosofia e teologia, sem receber gratificaçáo alguma dos seus alunos, e o que mais é, sustentando-os à sua custa ainda quando filhos de pessoas abastadas. O raro desinteresse com que assim se presta o Rev. Padre Marcos à ilustração de uma parte da mocidade de sua província, e geralmente a tudo que é de utilidade pública, tornando-o benemérito da não comum estima, que lhe consagram os seus concidadãos, única recompensa a que aspira e que tem recebido. Cheio de júbilo, senhores, aproveito a ocasiáo, em que falo em presença da província representada por seus delegados, para dar publicamente àquele cidadáo os louvores que merece por táo assinalados serviços. ${ }^{66}$

Esse relatório permite entrever um pouco do que foi a presença e a intervenção de Padre Marcos não somente para a educação, mas para a sociedade com que se relacionava, inscrevendo seu nome em significativas contribuiçóes para o Piauí e sua gente. Esse registro também expressa o respeito dedicado ao padre no cenário piauiense.

Seja no entorno ou no centro do comando político da província do Piauí, da vila de Jaicós, Padre Marcos mostrou sua força e deixou sua marca principalmente nas construçôes e nas açôes que favoreceu por meio de sua intervenção. Essas intervençôes geraram frutos, dentre os quais merece destaque o reconhecimento público de seus contemporâneos. Por retribuição aos serviços prestados à província, Padre Marcos recebeu as Cartas Imperiais de Cavaleiro e depois de Comendador da Ordem de Cristo, significativas insígnias do prestígio conquistado.

Atuou com destaque na cena política, social e cultural da província até o seu falecimento, em 4 de novembro de 1850, na fazenda de Boa Esperança, vila de Jaicós, ocasionado por

\footnotetext{
${ }^{66}$ PIAUÍ. APEPI. Relatório do Presidente da Provincia, Dr. Zacarias de Góes e Vasconcelos, a Assembleia legislativa provincial, em 11 de julho. Oeiras: Typ. Provincial. 1846.
} 
"um forte ataque apoplético", ${ }^{67}$ época em que ocupava a vice-presidência da província, no governo de José Antonio Saraiva, ${ }^{68}$ pondo fim ao trabalho desenvolvido na escola de Boa Esperança e a uma rica trajetória política, educacional e religiosa.

Sepultado na fazenda que tanto amou, recebeu ainda uma última retribuição do governo da província. Como homenagem póstuma, concedida por meio das leis provinciais no 463 e 497, de 1859, o governo da província autorizou a construção de um mausoléu na igreja matriz de Jaicós, onde foram depositados seus restos mortais. A construção dessa obra foi orçada em 2:000\$000 (dois contos de réis), ironicamente, valor próximo ao que a província lhe devia por seus gastos quando da construção da prisão de Jaicós.

Ajustes de contas ou reconhecimento merecido? O fato é que não é possível ignorar as páginas da história do Piauí que Padre Marcos, da vila de Jaicós, ajudou a escrever e que continuam sendo reescritas.

\section{Referências bibliográficas}

ARAÚJO, Emanuel. O teatro dos vícios: transgressão e transigência na sociedade urbana colonial. Rio de Janeiro: José Olympio, 1993.

BASTOS, Celso de Albuquerque. Dicionário histórico geográfico do estado do Piauí. Teresina: Fundação Cultural Monsenhor Chaves-PMT, 1994.

BRANDÃO, Tanya Maria Pires. Matrimônio: legalidade e sagração da família no Piauí colonial. In: SILVA, Maria Beatriz Nizza. Sexualidade, família e religião na colonização do Brasil. Lisboa: Livros Horizonte, 2001.

BRASIL. BIBLIOTECA NACIONAL. Mapa da divisão civil e eclesiástica da província do Piaui. 1856. Disponível em: <http://objdigital.bn.br/acervo_digital/div_manuscritos/mssII32_22_8. jpg >. Acesso em: 11 nov. 2008.

BRASIL. BIBLIOTECA NACIONAL. Mapa das cidades, vilas, lugares e freguesias das capitanias do Maranhão e Piauí. 1787. Disponível em: <http://objdigital.bn.br/acervo_digital/ div_cartografia/cart543219.jpg>. Acesso em: 11 nov. 2008.

BRASIL. RIO DE JANEIRO. Decreto de 6 de julho de 1832. Erige em villas varias povoaçóes da Provincia do Piauhy. In: Collecção das leis do Império do Brazil: primeira parte. Rio de Janeiro: Typographia Nacional, 1874.

CARVALHO JÚNIOR, Dagoberto Ferreira de. A talha de retábulos no Piauí. Recife: Comitê Norte Nordeste de História da Arte, 1990.

\footnotetext{
${ }^{67}$ PIAUÍ. APEPI. Ofício encaminhado ao Presidente da Provincia, José Antonio Saraiva, pelo juiz municipal Raimundo José de Carvalho e Sousa, dando conta do falecimento do Reverendo Padre Marcos de Araújo Costa. Sala do Poder Legislativo. Legislativo Municipal de Jaicós, cx: 92, 7 de novembro de 1850.

${ }^{68}$ PIAUÍ. APEPI. Resposta ao ofício do Juiz Municipal da Vila de Jaicós, Raimundo José de Carvalho e Sousa, dada pelo Presidente da Provincia, José Antonio Saraiva, sobre o falecimento de Padre Marcos de Araújo Costa. Legislativo Municipal, Jaicós, cx: 92, 16 de dezembro de 1850b.
} 
CASTELO BRANCO, Miguel de Sousa Borges Leal. Apontamentos biográficos de alguns piauienses e outras pessoas notáveis que ocuparam cargos de importância. Teresina: Tipografia da Imprensa, 1879.

CERTEAU, Michel de. A invenção do cotidiano: artes de fazer. Tradução de Ephrain F. Alves. Petrópolis, RJ: Vozes, 1994.

COSTA, Francisco Augusto Pereira da. Cronologia histórica do estado do Piauí. Rio de Janeiro: Artenova, 1974. v. I e II.

ELIAS, Norbert. A sociedade dos individuos. Rio de Janeiro: Jorge Zahar, 1994.

GARDNER, George. Viagem ao interior do Brasil, principalmente nas províncias do Norte e nos distritos do ouro e do diamante nos anos de 1836-1841. Traduçáo de Milton Amado. Apresentação de Mário Guimarães Ferri. Belo Horizonte: Itatiaia; São Paulo: Edusp, 1975. HAUCK, João Fagundes et. al. História da Igreja no Brasil: ensaio de interpretação a partir do povo: segunda época: século XIX. 4. ed. Petropólis, RJ: Vozes, 2008.

MELO, Cláudio. Fé e civilização. Teresina: [s.n.], 1991.

OLIVEIRA, José do Carmo. O bicentenário da paróquia de Nossa Senhora das Mercês de JaicósPiauí (1805-2005). Disponível em: <http://www.jaicos.com.paroquia200 htm>. Acesso em: 17 maio 2006.

PIAUÍ. APEPI. Atas do Conselho Geral da Província (1825-1829). 3ª seção de 10 de julho de 1829.

- Fala com que o Exmº Sr. Barão da Parnaiba [Manoel de Sousa Martins] abriu a sessáo ordinária da Assembleia [Legislativa] Provincial, em 13 de julho de 1837. Registro de Correspondência da Assembleia Legislativa com o Governo da Província, 1835-1843.

- Fala do Baráo da Parnaíba [Manoel de Sousa Martins] à Assembleia [Legislativa Provincial], no ato de sua instalação, em 4 de maio de 1835. Registro de Correspondência da Assembleia Legislativa com o Governo da Província, 1835-1843.

- Fala que recitou o Exmº Sr. Barão da Parnaíba [Manoel de Sousa Martins] Presidente desta Província do Piaui na ocasião da abertura da Assembleia Legislativa Provincial, no 9º de julho do ano de 1838. Sala do Poder Legislativo. Registro de Correspondência da Assembleia Legislativa com o Governo da Província, 1835-1843.

- Fala que recitou o Exmo Sr. Visconde da Parnaiba [Manoel de Sousa Martins] Presidente desta Provincia do Piaui na ocasião da abertura da Assembleia Legislativa Provincial, em 7 de julho de 1843. Sala do Poder Legislativo. Registro de Correspondência da Assembleia Legislativa com o Governo da Província, 1835-1843.

- Lei Provincial de 4 de outubro de 1838. Oeiras: Tipografia Oficial, 1838.

- Ofício da Assembleia Provincial ao Presidente, que dá conta das Receitas e Despesas das Câmaras Municipais no ano financeiro de 1ํ- de outubro de 1841 a 30 de setembro de 1842. Registro de Correspondência da Assembleia Legislativa, com o Governo da Província, 1835-1843. 
- Ofício da Câmara Municipal da Vila de Jaicós ao Presidente da Provincia, Dr. José Idelfonso de Sousa Ramos. Legislativo Municipal, Jaicós, cx: 93, 12 de abril de 1844.

- Ofício e Relatório encaminhado pela Câmara da Vila de Jaicós à Assembleia Provincial, prestando informaçôes sobre a representação impetrada por Luis Xavier de Araújo. Sala do Poder Legislativo. Legislativo, cx: 122, 1를 legislatura, de 4 de julho de 1837.

- Ofício encaminhado à Câmara de Jaicós, pela comissáo de fiscalização da construção da prisáo municipal, dando conta do andamento das obras. Sala do Poder Executivo, cx: 668-669, 30 de dezembro de 1844 .

Ofício encaminhado ao Presidente da Província, José Antonio Saraiva, pelo juiz municipal Raimundo José de Carvalho e Sousa, dando conta do falecimento do Reverendo Padre Marcos de Araújo Costa. Sala do Poder Legislativo. Legislativo Municipal de Jaicós, cx: 92, 7 de novembro de 1850 .

- Ofício encaminhado pela Câmara de Jaicós ao Presidente da Província, Barão da Parnaíba, dando conta da instalação da Câmara. Legislativo Municipal, Jaicós. cx: 93, 21 de fevereiro de 1834.

- Oficio encaminhado pela Câmara de Jaicós ao Presidente da Provincia, Barão da Parnaíba, encaminhando a lista dos jurados a servirem na vila. SPE. Jaicós. cx: 686, 17 de junho de 1834.

- Ofício encaminhado pela Câmara Municipal de Jaicós ao Presidente da Província, Dr. José Idelfonso de Sousa Ramos, informando as obras em execução na Vila. Legislativo Municipal, Jaicós, cx: 93, 3 de fevereiro de 1844.

- Oficio encaminhado pela Câmara Municipal de Jaicós ao Presidente da Provincia, Dr. José Idelfonso de Sousa Ramos, informando a comunicação e transportes da Vila. Legislativo Municipal, Jaicós, cx: 93, 14 de abril de 1844.

- Oficio encaminhado pela Câmara Municipal de Jaicós ao Presidente da Provincia, Barão da Parnaíba, solicitando a construção de uma prisão na Vila. Legislativo Municipal, Jaicós, cx: 93, 4 de julho novembro de 1836.

Oficio encaminhado pela Câmara Municipal de Jaicós ao Presidente da Provincia, Barão da Parnaíba, solicitando a construção de uma prisão na Vila. Legislativo Municipal, Jaicós, cx: 93, 3 de novembro de 1834.

. Posturas policiais do município da vila de Jaicós, Art. 36. Sala do Poder Legislativo. Legislativo Municipal de Jaicós, cx: 92, de 4 de outubro de 1834.

. Relatório do Presidente da Província, Dr. Zacarias de Góes e Vasconcelos, a Assembleia legislativa provincial, em 11 de julho. Oeiras: Typ. Provincial, 1846.

- Resolução no 96, de 4 de outubro de 1838. Obriga aos possuidores de roças no distrito do municipio de Amarante a apresentarem anualmente vinte cabeças de periquitos ou outro animal danoso à agricultura. Sala do Poder Legislativo/02, Documentos Avulsos/02, 1838. 
- Resposta ao ofício do Juiz Municipal da Vila de Jaicós, Raimundo José de Carvalho e Sousa, dada pelo Presidente da Provincia, José Antonio Saraiva, sobre o falecimento de Padre Marcos de Araújo Costa. Legislativo Municipal, Jaicós, cx: 92, 16 de dezembro de 1850.

- Resposta da Assembleia Legislativa Provincial à fala do Presidente da Provincia, de 1838. Sala do Poder Legislativo. Registro de Correspondência da Assembleia Legislativa, com o Governo da Província, 1835-1843.

PIAUÍ. Lei Estadual n. 2.566. Cria o município de Padre Marcos. Teresina, 20 jan. 1964.

RAFAEL FILHO, José. $O$ galo na torre. Disponível em: <http://www.jaicos.com/ paroquia200.html>. Acesso em: 26 fev. 2007. . Sobre a história religiosa de Jaicós. Jaicós, PI: [s.n.], 2008. mimeo.

REVEL, Jacques. Jogos de escalas: a experiência da microanálise. Rio de Janeiro: Fundação Getulio Vargas, 1998.

SOARES FILHO, Antonio Reinaldo. Oeiras municipal. Teresina: Gráfica Editora Junior, 1992.

SODRÉ, Nelson Wernek. Panorama do segundo império. 2. ed. Rio de Janeiro: Graphia, 1998.

\section{Como citar:}

NETO, Marcelo de Sousa. O padre, a vila e o galo da torre: padre Marcos de Araújo Costa e a vila de Jaicós (Piauí, 1832-1850). Topoi. Revista de História, Rio de Janeiro, v. 19, n. 38, p. 241-262, mai./ago. 2018. Disponível em: <www.revistatopoi.org>. 